\title{
Mineral chemistry of tantalate species new in the Borborema Pegmatitic Province, Northeast Brazil
}

\author{
HARTMUT BEURLEN ${ }^{1}$, DWIGHT R. SOARES ${ }^{2}$, RAINER THOMAS ${ }^{3}$ \\ LUCILA E. PRADO-BORGES ${ }^{1}$ and CLÁUdIO DE CASTRO ${ }^{1}$ \\ ${ }^{1}$ Universidade Federal de Pernambuco, UFPE, Depto. Engenharia de Minas \\ Rua Acad. Hélio Ramos s/n, 50740-530 Recife, PE, Brasil \\ ${ }^{2}$ Programa de Pós-Graduação em Geociências da UFPE \\ Rua Acad. Helio Ramos s/n, 50740-530 Recife, PE, Brasil \\ ${ }^{3}$ GeoForschungsZentrum Potsdam, Alemanha, Telegraphenberg B 120, D14473 Potsdam \\ Manuscript received on October 15, 2003; accepted for publication on August 13, 2004; \\ presented by ALCIDES N. SIAL
}

\begin{abstract}
Tantalate samples, supposedly of the columbite group, were collected in the Borborema Pegmatitic Province, aiming to test the $\mathrm{Mn} /(\mathrm{Mn}+\mathrm{Fe})$ and $\mathrm{Ta} /(\mathrm{Ta}+\mathrm{Nb})$ ratios as geochemical indicators of pegmatite fractionation. Surprisingly, preliminary microprobe data allowed recognizing some species, so far unknown in the Province, namely titanian ixiolite, fersmite, brannerite, strüverite, natrobistantite, plumbo- and stibiomicrolite, plumboand uranpyrochlore. The identification of these exotic tantalates with unusual composition, in addition to its distribution in several pegmatites, far from the classical Alto do Giz and Seridozinho pegmatites, indicate that the elevated degree of fractionation is not restricted to these two occurrences but may be reached in other pegmatite areas of the Province. It indicates also that this degree of fractionation may be very variable between pegmatites in small areas. The zoning patterns observed in the titanian ixiolite, with $\mathrm{Ti}$ and $\mathrm{Nb}$ enrichment at the borders at expense of Ta enriched in the core, are also quite unusual and reverse in comparison with the normal trend of progressive Ta and Mn enrichment in tantalates with the degree of fractionation. A similar "reverse" trend was observed in titanian wodginite of petalite/pollucite bearing pegmatites of the Separation Rapids Province in Ontario, Canada.
\end{abstract}

Key words: titanian ixiolite, fersmite, brannerite, strüverite, niobium-tantalates, pegmatites, Northeast Brazil.

\section{INTRODUCTION}

The Borborema Pegmatitic Province (BPP) approximately overlaps the eastern and southeastern part of the Neoproterozoic Seridó Foldbelt, between $6^{\circ}$ and $7^{\circ} \mathrm{S}$ and $36^{\circ} 15^{\prime}$ and $36^{\circ} 45^{\prime} \mathrm{W}$, in the States of Rio Grande do Norte and Paraíba, in Northeast Brazil. The Seridó Foldbelt is a Neoproterozoic unit

Correspondence to: Hartmut Beurlen

E-mail: beurlen@ufpe.br of the Borborema Tectonic Province (Fig. 1). It is composed of a basal sequence of meta-volcanosedimentary rocks (Jucurutu Formation), followed by quartzites and metaconglomerates of the Equador Formation, overlain by a turbidite-flysch sequence (biotite schists of the Seridó Formation). The pegmatites of the BPP are supposedly related to peraluminous to metaluminous I type granites formed during the last of four main stages of granite intrusions (Da Silva et al. 1995). The best age 
estimates of the pegmatites range between 450 and $510 \mathrm{Ma}$ (Ebert 1969 - U/Pb in uraninite, Almeida et al. 1968, $-\mathrm{Rb} / \mathrm{Sr}$ and $\mathrm{K} / \mathrm{Ar}$ in muscovite). According to Da Silva et al. (1995), there were registered about 1,500 pegmatite occurrences. Several hundreds of them were known worldwide since the 1940ies because of its important Ta, Li, Be production and also as producers of beautiful specimens of exotic tantalate species, some of them referred in the literature as type locality, such as the Alto do Giz for Simpsonite, Natrotantite, Alumotantite, Parabariomicrolte and Seridozinho for Staringite, Raposa pegmatite for Tantalaeschynite-Y and the Quixaba pegmatite for Fluornatromicrolite (Atêncio 2000).

In contrast with this importance, systematic and detailed studies on $\mathrm{Ta}-\mathrm{Nb}$ bearing minerals of the BPP are very scarce and restricted to a few authors (e.g. Johnston Jr. 1945, Rolff 1946, Adusumilli 1978, Ercit et al. 1985, 1986, 1992a, e, Burke et al. 1969, 1970). More recent studies lack completely.

During the sampling for fluid inclusion (Beurlen et al. 2001) and lithogeochemistry studies of the Quintos pegmatite in the BPP some "black ore' minerals, supposed to be of the tantalitecolumbite group accidentally found, were also collected and examined, aiming to determine the $\mathrm{Mn} /$ $(\mathrm{Mn}+\mathrm{Fe})$ and $\mathrm{Ta} /(\mathrm{Ta}+\mathrm{Nb})$ ratios, and to check their utility as indicator of the degree of fractionation of the hosting pegmatite. Surprisingly the petrographic examination of some polished sections allowed the recognition that the ore was composed of several different phases instead of single columbite or tantalite crystals. Preliminary microprobe (EMP) and scanning electron microscope (SEM) analyses revealed compositions matching approximately those of very titanium rich ixiolites or wodginites, niobian rutile, brannerite and natrobistantite. Taking in account that among these minerals only one occurrence of niobian rutile was known in the BPP, these samples were submitted to a more detailed examination together with a series of samples from other seventeen pegmatites.

\section{MATERIALS AND METHODS}

The samples of the Boqueirão, Quintos and Capoeiras pegmatites referred to in this study were collected by the authors. In these cases the exact location and paragenetic position of the minerals in the structure of the host pegmatites are known. The samples of the Corredor and Serraria pegmatites were obtained directly from miners and "garimpeiros" (precious stone seekers) at the entrance of the mine excavations, so the exact location can only be induced in those cases where the tantalates are still part of a larger sample with other pegmatite minerals. In the case of samples from other pegmatites the provenance was informed by garimpeiros and mineral dealers.

In a first step polished sections of 30 samples from 17 pegmatites were studied petrographically and X-ray diffractograms were obtained. Those samples where the X-ray diffractograms and/or the petrographic characteristics indicated the presence of phases other than normal columbite/tantalite or cassiterite, were submitted to more detailed analyses by electron microprobe (EMP) and/or scanning electronic microscope (SEM). During this procedure, in addition to the new tantalate species focused in this paper, it was possible to identify six new occurrences of ferrotapiolite, two of ferrowodginite and two of niobian rutile. These findings are a clear indication that a systematic study of the "blak ores" in the BPP is still of great interest.

The X-ray diffractograms were obtained using a D 5000 Siemens X-ray Diffractometer and a CuKa tube in the Department of fundamental Chemistry of the Federal University of Pernambuco.

Preliminary EMP analyses were obtained with a JEOL JXA 8600 at $20 \mathrm{kV}, 40 \mathrm{nA}$, acquisition times of 20 seconds for major, 30 for minor and 40 seconds for trace elements and the following standards: $\mathrm{TiO}_{2}$ ( Ti $\mathrm{K} \alpha), \mathrm{Nb}(\mathrm{Nb} \mathrm{L} \alpha)$, Ta (Ta M $\alpha)$, Sn (Sn L $\alpha)$, Anorthite $(\mathrm{Al} \mathrm{K} \alpha)$, Olivine $(\mathrm{Fe} \mathrm{K} \alpha)$, Wolastonite $(\mathrm{Ca} \mathrm{K} \alpha)$, Spessartite $(\mathrm{Mn} \mathrm{K} \alpha), \mathrm{Bi}(\mathrm{Bi} \mathrm{M} \alpha)$, in the EMP lab of the University of São Paulo (USP). 


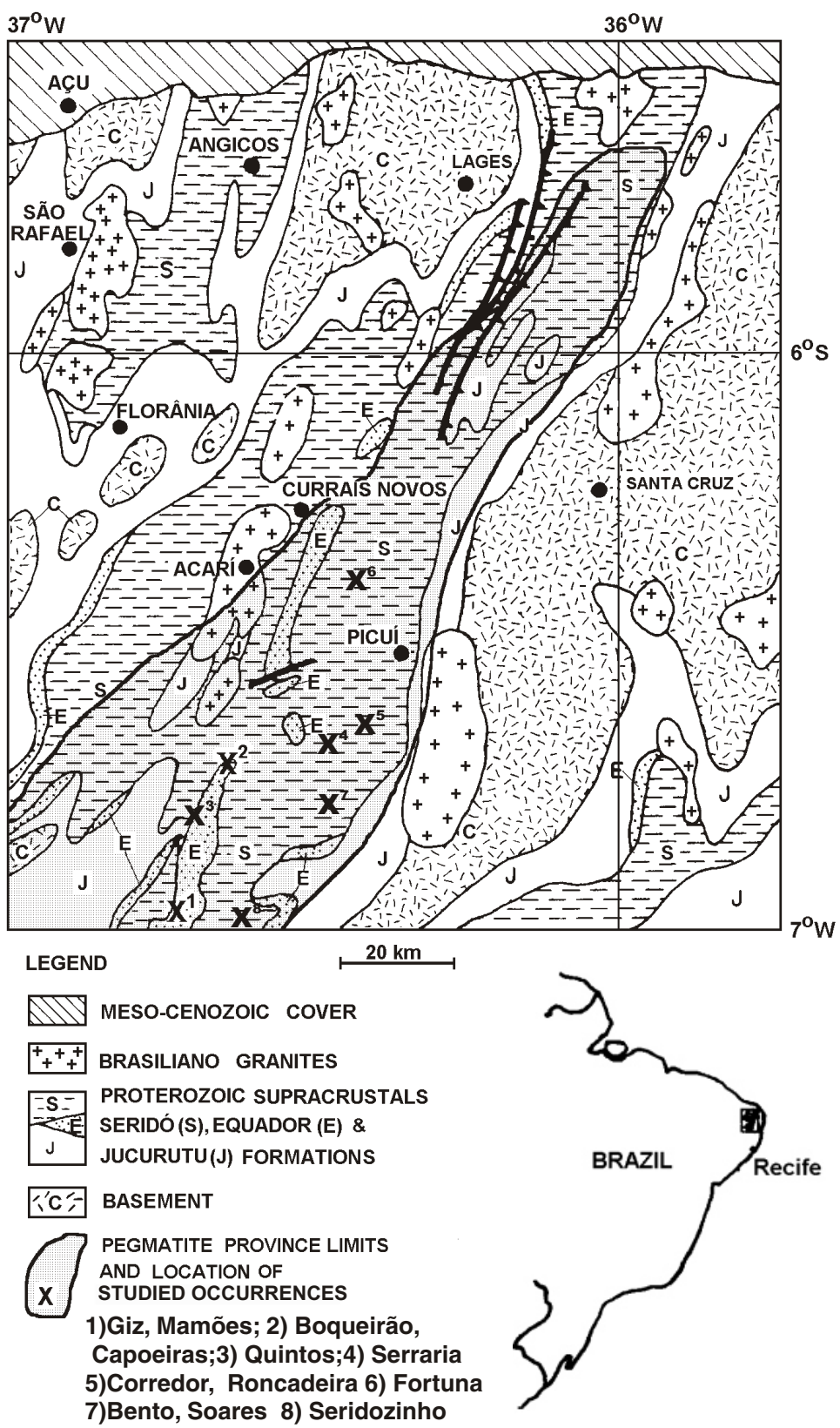

Fig. 1 - Simplified geologic map of the Seridó Foldbelt, modified from Jardim de Sá et al. 1981 and Brito Neves et al. (1995), displaying the extension of the Borborema Pegmatitic Province and the situation of the pegmatites referred to in the text.

Follow up EMP analyses were obtained at the GeoForschungsZentrum Potsdam-Germany, using a Cameca SX 50 EMP at $20 \mathrm{kV}$ and $40 \mathrm{nA}$ using the following standards: albite, apatite (Durango), flu- orite, ilmenite, cassiterite, orthoclase, rutile, titanite ( $\mathrm{Si}, \mathrm{Ca}, \mathrm{Ti}$ ), zircon, $\mathrm{Nb}^{\circ}, \mathrm{Ta}^{\circ}, \mathrm{Th}^{\circ}, \mathrm{U}^{\circ}, \mathrm{BaSO}_{4}$, $\mathrm{CePO}_{4}, \mathrm{LaPO}_{4}, \mathrm{YPO}_{4}, \mathrm{ScPO}_{4}, \mathrm{InSb}, \mathrm{MgO}, \mathrm{HfO}_{2}$, $\mathrm{MnTiO}_{3}$. 
The SEM analyses were obtained at the University of Campinas São Paulo using a SEM leo 430i, Cambridge, EDS mod. Cat. B, using the following working conditions: $20 \mathrm{Kv}, 30$ seconds acquisition time, using the following standards: $\mathrm{Ta}^{\circ}(\mathrm{Ta} \mathrm{M} \alpha$ ), $\mathrm{Nb}^{\circ}(\mathrm{Nb} \mathrm{L} \alpha), \mathrm{Sn}^{\circ}(\mathrm{Sn} \mathrm{L} \alpha), \mathrm{Ti}^{\circ}(\mathrm{Ti} \mathrm{K} \alpha), \mathrm{V}^{\circ}(\mathrm{V} \mathrm{K} \alpha)$, $\mathrm{Sb}^{\circ}(\mathrm{Sb} \mathrm{L} \alpha), \mathrm{Bi}^{\circ}(\mathrm{Bi} \mathrm{M} \alpha), \mathrm{Zr}^{\circ}(\mathrm{Zr} \mathrm{L} \alpha), \mathrm{U}^{\circ}(\mathrm{UM} \alpha)$, $\mathrm{Hf}^{\circ}(\mathrm{Hf} \mathrm{M} \alpha), \mathrm{PbF}_{2}(\mathrm{~Pb} \mathrm{M} \alpha), \mathrm{BCR}_{2}(\mathrm{Fe} \mathrm{K} \alpha, \mathrm{Mn} \mathrm{K} \alpha$, Al $\mathrm{K} \alpha, \mathrm{Ca} \mathrm{K} \alpha, \mathrm{Na} \mathrm{K} \alpha$, Si K $\alpha, \mathrm{K} \mathrm{K} \alpha$ ).

The calculation procedure to obtain the cationic composition (atoms per formula unit $=\mathbf{a p f u}$ ) listed in Tables I and II, was to normalize them in a first step to a sum of 24 oxygens for most tantalates to allow an easier comparison between them. In a second step, when the obtained cation sum surpassed the corresponding theoretical value (12 for the columbite group, tapiolite, ixiolite, niobian rutile, struverite, fersmite, cassiterite etc.) the $\mathrm{Fe}^{2+}$ content was partially converted to $\mathrm{Fe}^{3+}$ (according to Ercit et al. $1992 \mathrm{~b}, \mathrm{c})$ by trial and error until the cation sum reached the value of $12.0000 \pm 0.0002$. The pyrochlore group minerals were normalized to a cation sum of 8 in the $\mathrm{B}(\mathrm{Nb}, \mathrm{Ta}, \mathrm{Ti}, \mathrm{Sn}, \mathrm{W}, \mathrm{Si}$, $\mathrm{P}, \mathrm{Al})$ site.

\section{MINERAL PETROGRAPHY AND CHEMISTRY}

Brannerite $\left(\mathrm{UTi}_{2} \mathrm{O}_{6}\right)$ was identified in a sample of the transition between the border zone and zone II (wall zone) of the Quintos Pegmatite, intruded in the quartzites of the Equador formation. The contact (border) zone of this pegmatite is formed by albite, quartz and comb textured black tourmaline (dravite) with subordinated apatite, muscovite, magnetite, ilmenite and garnet. Zone II is composed of quartz, albite, white mica and perthitic microcline, with subordinated garnet and tourmaline (Figure 2). The brannerite was found as a single grain enclosed in quartz and in part by white mica, a few cm far from an aggregate of lamellar to tabular crystals of titanian ixiolite. The rounded, isometric grain of brannerite is about $4 \mathrm{~mm}$ large in diameter, presents a dark brownish to black color and peaty luster. A brownish halo in the quartz around the grain and its con- choidal fracture led to the suspicion of its metamictic nature, reinforced by the observation in polished section under microscope of an internal collomorphic to nodular microtexture and strong variation of reflectivity. Weak brownish internal reflections are also observed and no apparent anisotropism. The small size of the grain and the metamictic character precluded the acquisition of a good diffractogram.

The chemical composition matches the values referred to by Antony et al. (1997) with about $56 \mathrm{wt} \% \mathrm{UO}_{2}$ and 23-27 wt $\% \mathrm{TiO}_{2}$, as main constituents, and minor amounts of, $\mathrm{Fe}, \mathrm{Ca}, \mathrm{Th}, \mathrm{Pb}, \mathrm{Mn}$ and $\mathrm{Ce}$ (Table I). While this well individualized grain according to its convex form against quartz and mica can be considered as primary-magmatic in origin, a very small, 20 micra sized grain was observed in a fracture within a titanian ixiolite crystal as product of hydrothermal alteration, together with hematite, uranmicrolite and uranpyrochlore (Figure 3D).

Titanian ixiolite $\left\{(\mathrm{Mn}, \mathrm{Fe}, \mathrm{Ta}, \mathrm{Nb}, \mathrm{Sn}, \mathrm{Ti})_{4} \mathrm{O}_{8}\right\}$ is the tentative identification of several small idiomorphic tabular crystals up to 2 by 4 by $10 \mathrm{~mm}$ in size, found a few centimeter far from the previously described brannerite at the transition between the border zone and the wall zone (homogeneous pegmatite) of the Quintos pegmatite (Figure 2). The mineral presents a metallic luster, dark grey color and irregular fractures without apparent cleavage. The examination of polished sections under microscope reveals a reflectivity very close, but slightly higher than that of manganocolumbite inclusions, more intensive anisotropy and internal reflections, and very similar polishing hardness. The effective distinction from manganocolumbite was assured only by the unusual composition obtained by microprobe analyses with $\mathrm{TiO}_{2}, \mathrm{Nb}_{2} \mathrm{O}_{5}, \mathrm{Ta}_{2} \mathrm{O}_{5}$ and $\mathrm{Fe}_{2} \mathrm{O}_{3}$ contents ranging from 14 to $52 \mathrm{wt} \%, 17$ to $38 \mathrm{wt} \%, 11$ to $43 \mathrm{wt} \%$, and 17 to $24 \mathrm{wt} \%$ respectively. This large range in composition is observed in a single crystal that shows oscillatory compositional zoning with a general trend of enrichment of the heavy elements $(\mathrm{Ta}+\mathrm{Nb})$ in the core and of $\mathrm{Ti}$ and $\mathrm{Nb}$ in the rim (Fig. 4C, Table II). These com- 


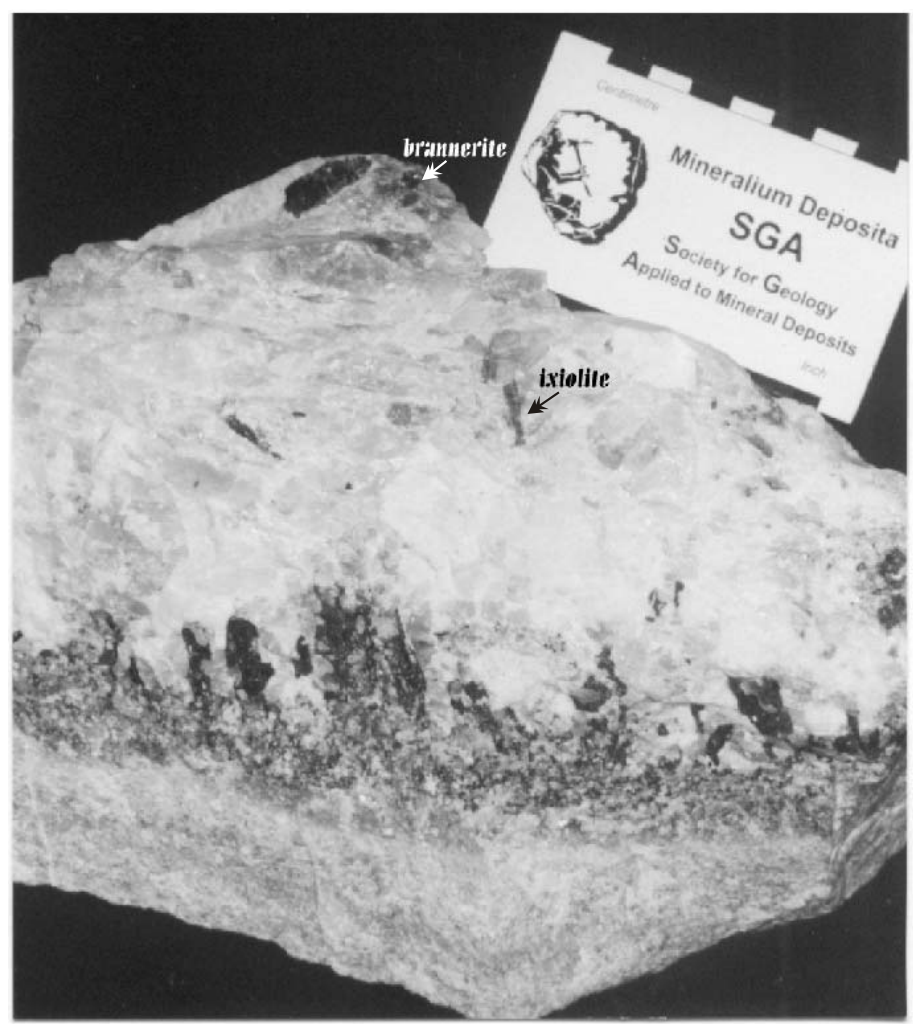

Fig. 2 - Sample from the border zone of the Quintos pegmatite with the enclosing quartzites at the bottom, followed by a first contact zone with quartz, albite and comb-textured black dravite growing perpendicularly from the wall to the interior of the pegmatite. Ixiolite and brannerite (arrows) occur in the beginning of the zone II ("wall zone"), which is formed by albite quartz and subordinated K-feldspar, muscovite, and dravite. Apatite, zircon and garnet are small grain-size accessory minerals in both zones.

positions, in a triangular plot of $\mathrm{Ti}, \mathrm{Sn}$ vs. $\mathrm{Fe}, \mathrm{Mn}$ vs. $\mathrm{Nb}, \mathrm{Ta}(\mathrm{apfu})$ lie along a linear trend between usual niobian rutile, titanowodginite and titanian ixiolite compositions, filling a gap observed by Uher et al. (1998a) and Černý et al. (1998), between naturally coexisting niobian rutile and titanian ixiolite or titanowodginites. The X-ray diffractogram presents a pattern with a few peaks similar to, but slightly dislocated from the main peaks of the type ixiolite, titanowodginite and columbite (Beurlen et al. 2003). The main peaks of strüverite and niobian rutile are lacking completely, so these species can be eliminated (Fig. 5). The cationic composition al- lows to eliminate the identification as a mineral of the wodginite group, because of low sums of elements in the $\mathrm{A}(\mathrm{Li}, \mathrm{Fe}, \mathrm{Mn})$ and $\mathrm{C}(\mathrm{Ta}, \mathrm{Nb}, \mathrm{W})$ sites. Ti values as high as in the studied case have never been observed in the columbite or wodginite family (Černý and Ercit 1985, Ercit et al. 1992d, Aurisichio et al. 2002), but are to low in comparison with those of niobian rutile and strüverite. So, the most probable and preliminary identification must be as an unusual high titanian ixiolite. The identification as a new mineral species can also not be discarded.

Unusual in this mineral is also the pattern of compositional zoning with enrichment of $\mathrm{Ti}$ and $\mathrm{Nb}$ 
TABLE I

Representative microprobe analyses of tantalate mineral species new in the BPP.

Na-Bi-microlite and fersmite data obtained at USP, strüverite at GFZP, brannerite, microlites and pyrochlores data obtained at both, USP and GFZP.

\begin{tabular}{|c|c|c|c|c|c|c|c|c|c|c|}
\hline \multirow[b]{3}{*}{$\mathrm{wt} \%$} & \multirow{3}{*}{$\begin{array}{c}\text { Brannerite } \\
\mathrm{N}=20\end{array}$} & \multirow{3}{*}{$\begin{array}{c}\text { Fersmite } \\
\qquad \mathrm{N}=1\end{array}$} & \multirow{3}{*}{$\begin{array}{c}\text { Struverite } \\
\mathrm{N}=15\end{array}$} & \multicolumn{2}{|c|}{ Pyrochlores } & \multicolumn{5}{|c|}{ Microlites } \\
\hline & & & & $\mathrm{Pb}$ & $\mathrm{U}$ & F-Na & $\mathrm{Ba}$ & $\mathrm{Pb}$ & $\mathrm{Sb}$ & $\mathrm{Na}-\mathrm{Bi}$ \\
\hline & & & & $\mathrm{N}=3$ & $\mathrm{~N}=1$ & $\mathrm{~N}=8$ & $\mathrm{~N}=3$ & $\mathrm{~N}=1$ & $\mathrm{~N}=5$ & $\mathrm{~N}=3$ \\
\hline $\mathrm{Ta}_{2} \mathrm{O}_{5}$ & 0.22 & 11.3 & 44.90 & 11.60 & 5.06 & 80.92 & 81.22 & 78.92 & 76.36 & 63.90 \\
\hline $\mathrm{Nb}_{2} \mathrm{O}_{5}$ & 0.76 & 69.90 & 7.05 & 26.17 & 28.78 & 1.11 & 1.10 & 0.71 & 0.64 & 5.00 \\
\hline $\mathrm{TiO}_{2}$ & 25.90 & 2.30 & 29.28 & 2.20 & 0.87 & 0.00 & 0.00 & 0.00 & 0.00 & 0.00 \\
\hline $\mathrm{MnO}$ & 0.23 & 0.30 & 0.06 & 0.05 & 4.08 & 0.03 & 0.04 & 0.01 & 0.05 & 1.40 \\
\hline $\mathrm{FeO}$ & 4.91 & 0.30 & 12.25 & 11.09 & 3.33 & 0.00 & 0.02 & 0.00 & 0.01 & 0.00 \\
\hline $\mathrm{SnO}_{2}$ & 0.00 & 0.00 & 6.21 & 0.01 & 0.00 & 0.02 & 0.03 & 0.04 & 0.04 & 0.00 \\
\hline $\mathrm{MgO}$ & 0.02 & 0.00 & 0.05 & 0.18 & 0.07 & 0.00 & 0.00 & 0.00 & 0.01 & 0.00 \\
\hline $\mathrm{CaO}$ & 1.36 & 16.60 & 0.00 & 0.99 & 0.19 & 9.02 & 0.29 & 0.01 & 0.74 & 2.70 \\
\hline $\mathrm{Na}_{2} \mathrm{O}$ & 0.01 & 0.00 & 0.00 & 0.72 & 0.08 & 5.35 & 0.13 & 0.11 & 0.91 & 1.30 \\
\hline $\mathrm{K}_{2} \mathrm{O}$ & 0.00 & nd & 0.00 & 0.62 & 1.44 & 0.01 & 0.11 & 0.01 & 0.15 & nd \\
\hline $\mathrm{Al}_{2} \mathrm{O}_{3}$ & 0.56 & 0.00 & 0.08 & 1.81 & 0.04 & 0.00 & 0.05 & 0.03 & 0.02 & 0.00 \\
\hline $\mathrm{UO}_{2}$ & 55.50 & 0.00 & 0.00 & 8.94 & 41.52 & 0.02 & 0.02 & 0.11 & 0.02 & 0.00 \\
\hline $\mathrm{ZrO}_{2}$ & 0.01 & nd & 0.21 & 0.32 & 0.45 & 0.05 & 0.15 & 0.10 & 0.16 & nd \\
\hline $\mathrm{HfO}_{2}$ & 0.06 & nd & 0.03 & 0.00 & 0.11 & 0.00 & 0.00 & 0.00 & 0.00 & nd \\
\hline $\mathrm{ThO}_{2}$ & 1.75 & nd & 0.01 & 0.00 & 0.07 & 0.03 & 0.02 & 0.01 & 0.02 & nd \\
\hline $\mathrm{Sc}_{2} \mathrm{O}_{3}$ & 0.00 & nd & 0.09 & 0.00 & 0.00 & 0.13 & 0.21 & 0.22 & 0.33 & nd \\
\hline $\mathrm{Ce}_{2} \mathrm{O}_{3}$ & 0.06 & nd & 0.15 & 0.09 & 0.00 & 0.21 & 0.47 & 0.26 & 0.26 & $\overline{\text { nd }}$ \\
\hline $\mathrm{Bi}_{2} \mathrm{O}_{3}$ & nd & 0.10 & nd & & nd & nd & nd & nd & nd & 19.90 \\
\hline $\mathrm{Sb}_{2} \mathrm{O}_{3}$ & 0.00 & nd & 0.00 & 0.00 & 0.00 & 0.84 & 2.20 & 1.19 & 9.15 & $\mathrm{nd}$ \\
\hline $\mathrm{PbO}$ & 3.11 & nd & 0.00 & 15.92 & 0.55 & 0.92 & 2.51 & 7.34 & 4.09 & nd \\
\hline $\mathrm{BaO}$ & 0.00 & nd & 0.00 & 0.00 & 0.16 & 0.00 & 4.58 & 1.85 & 0.62 & nd \\
\hline $\mathrm{F}$ & 0.00 & nd & 0.00 & 0.00 & 0.00 & 3.53 & 0.18 & 0.18 & 0.26 & nd \\
\hline $\mathrm{P}_{2} \mathrm{O}_{5}$ & 0.00 & nd & 0.00 & 3.78 & 0.35 & 0.00 & 0.00 & 0.00 & 0.00 & nd \\
\hline $\mathrm{SiO}_{2}$ & 0.34 & nd & 0.00 & 0.58 & 0.00 & 0.00 & 0.00 & 0.00 & 0.00 & nd \\
\hline total & 95.41 & 100.80 & 100.36 & 85.53 & 87.94 & 102.19 & 93.32 & 91.08 & 93.84 & 94.30 \\
\hline \multicolumn{11}{|l|}{ apfu } \\
\hline $\mathrm{Ta}$ & 0.02 & 0.68 & 2.91 & 1.11 & 0.73 & 7.82 & 7.82 & 7.88 & 7.88 & 7.09 \\
\hline $\mathrm{Nb}$ & 0.11 & 6.98 & 0.76 & 4.17 & 6.92 & 0.18 & 0.18 & 0.12 & 0.11 & 0.90 \\
\hline $\mathrm{Ti}$ & 6.07 & 0.38 & 5.25 & 0.58 & 0.35 & 0.00 & 0.00 & 0.00 & 0.00 & 0.01 \\
\hline $\mathrm{Mn}$ & 0.06 & 0.05 & 0.01 & 0.15 & 1.84 & 0.01 & 0.01 & 0.00 & 0.02 & 0.38 \\
\hline $\mathrm{Fe}^{3+}$ & 1.28 & 0.06 & 1.06 & 0.00 & 0.00 & 0.00 & 0.00 & 0.00 & 0.00 & 0.00 \\
\hline $\mathrm{Fe}^{2+}$ & 0.00 & 0.00 & 1.39 & 3.27 & 1.48 & 0.00 & 0.01 & 0.00 & 0.00 & 0.00 \\
\hline $\mathrm{Sn}$ & 0.00 & 0.00 & 0.59 & 0.00 & 0.00 & 0.00 & 0.00 & 0.01 & 0.01 & 0.00 \\
\hline $\mathrm{Mg}$ & 0.00 & 0.00 & 0.00 & 0.09 & 0.05 & 0.00 & 0.00 & 0.00 & 0.00 & 0.00 \\
\hline $\mathrm{Ca}$ & 0.45 & 3.93 & 0.00 & 0.37 & 0.11 & 3.43 & 0.11 & 0.01 & 0.30 & 0.74 \\
\hline $\mathrm{Na}$ & 0.00 & 0.00 & 0.00 & 0.49 & 0.08 & 3.69 & 0.09 & 0.08 & 0.69 & 1.15 \\
\hline $\mathrm{K}$ & 0.00 & nd & 0.00 & 0.28 & 0.97 & 0.00 & 0.05 & 0.00 & 0.07 & $\mathrm{nd}$ \\
\hline $\mathrm{Al}$ & 0.20 & 0.00 & 0.02 & 0.75 & 0.02 & 0.00 & 0.02 & 0.01 & 0.01 & 0.00 \\
\hline
\end{tabular}


TABLE I ( continuation )

\begin{tabular}{|c|c|c|c|c|c|c|c|c|c|c|}
\hline \multirow[b]{3}{*}{ wt $\%$} & \multirow[t]{2}{*}{ Brannerite } & \multirow[t]{2}{*}{ Fersmite } & \multirow[t]{2}{*}{ Struverite } & \multicolumn{2}{|c|}{ Pyrochlores } & \multicolumn{5}{|c|}{ Microlites } \\
\hline & & & & $\mathrm{Pb}$ & $\mathrm{U}$ & $\mathrm{F}-\mathrm{Na}$ & $\mathrm{Ba}$ & $\mathrm{Pb}$ & $\mathrm{Sb}$ & $\mathrm{Na}-\mathrm{Bi}$ \\
\hline & $\mathrm{N}=20$ & $\mathrm{~N}=1$ & $\mathrm{~N}=15$ & $\mathrm{~N}=3$ & $\mathrm{~N}=1$ & $\mathrm{~N}=8$ & $\mathrm{~N}=3$ & $\mathrm{~N}=1$ & $\mathrm{~N}=5$ & $\mathrm{~N}=3$ \\
\hline $\bar{U}$ & 4.09 & 0.00 & 0.00 & 0.74 & 5.22 & 0.00 & 0.00 & 0.01 & 0.00 & 0.00 \\
\hline $\mathrm{Zr}$ & 0.00 & nd & 0.02 & 0.05 & 0.12 & 0.01 & 0.03 & 0.02 & 0.03 & nd \\
\hline $\mathrm{Hf}$ & 0.01 & nd & 0.00 & 0.00 & 0.02 & 0.00 & 0.00 & 0.00 & 0.00 & nd \\
\hline Th & 0.12 & nd & 0.00 & 0.00 & 0.01 & 0.00 & 0.00 & 0.00 & 0.00 & nd \\
\hline $\mathrm{Sc}$ & 0.00 & nd & 0.02 & 0.00 & 0.00 & 0.04 & 0.06 & 0.07 & 0.11 & nd \\
\hline $\mathrm{Ce}$ & 0.01 & nd & 0.01 & 0.01 & 0.00 & 0.03 & 0.06 & 0.04 & 0.04 & nd \\
\hline $\mathrm{Bi}$ & 0.00 & 0.00 & nd & 0.00 & 0.00 & 0.00 & 0.00 & 0.00 & 0.00 & 2.44 \\
\hline $\mathrm{Sb}$ & 0.00 & 0.00 & 0.00 & 0.00 & 0.00 & 0.12 & 0.32 & 0.18 & 1.45 & nd \\
\hline $\mathrm{Pb}$ & 0.17 & nd & 0.00 & 1.51 & 0.08 & 0.09 & 0.24 & 0.73 & 0.42 & nd \\
\hline $\mathrm{Ba}$ & 0.00 & nd & 0.00 & 0.00 & 0.03 & 0.00 & 0.64 & 0.27 & 0.09 & nd \\
\hline $\mathrm{F}$ & 0.00 & nd & 0.00 & 0.00 & 0.00 & 3.93 & 0.20 & 0.21 & 0.32 & nd \\
\hline $\mathrm{P}$ & 0.00 & nd & 0.00 & 1.13 & 0.16 & 0.00 & 0.00 & 0.00 & 0.00 & nd \\
\hline $\mathrm{Si}$ & 0.05 & nd & 0.00 & 0.20 & 0.00 & 0.00 & 0.00 & 0.00 & 0.00 & nd \\
\hline Total & 12.27 & 12.09 & 12.00 & 14.92 & 18.19 & 15.43 & 9.64 & 9.41 & 11.23 & 12.71 \\
\hline B site & & & & 8.00 & 8.00 & 8.00 & 8.00 & 8.00 & 8.00 & 8.00 \\
\hline
\end{tabular}

towards the border of the crystals while the expected zonation of tantalates is that of a late Ta and $\mathrm{Mn}$ enrichment at expense of $\mathrm{Fe}$ and $\mathrm{Nb}$. Similar zoning trends were observed by Tindle et al. (1998) in columbites and wodginites of Cs-Li producing pegmatites of the Separation Rapids Pegmatitic Field in Canada and classified by Tindle and Breaks (2000) as a reverse zoning pattern.

Fersmite $\left(\mathrm{CaNb}_{2} \mathrm{O}_{6}\right)$ was observed only in polished sections, in fractures of the titanian ixiolite, or as syntaxial overgrowths on micro-radial aggregates of tabular crystals (ten by thirty micra sized), of Ca- Ti-bearing manganocolumbite (Fig. 3C). The reflectivity of the fersmite lamellae in comparison with the columbite is clearly lower and the reflection pleochroism and internal reflections distinctly more intense. Several SEM spectra and an EMP analysis (Table I) match perfectly those of fersmite data from the literature (Uher et al. 1998b, Antony et al. 1997) and are also almost identical to the ideal formula. The position in fractures, together with several minerals of the pyrochlore group (uranmicrolite, plumbo- and uranpyrochlore), ilmeno- hematite, hematite, clearly indicates the secondary origin of fersmite by a late stage of hydrothermal alteration usual in evolved pegmatites (Uher et al. 1998b).

Natrobistantite (or Sodic-caesian-calcic bismutomicrolite, NBT from now on) was found in the Quintos Pegmatite within replacement pockets formed by lamellar albite and quartz aggregates, with sporadic idiomorphic pink to light blue zoned gemologic crystals of elbaite (the famous Paraíba tourmaline) and rare niobian rutile crystals. The NBT occurs as up to $5 \mathrm{~mm}$ sized irregular shaped grains, xenomorphic against albite and quartz, indicating a late formation. In polished sections and under the petrographic microscope they present a collomorphic to sphaerulitic internal microtexture and strongly - but gradually - variable reflectivity and polishing microhardness, due to its metamictic nature. The maximal reflectivity is lower than that of niobian rutile found in the same section, similar to ilmenite but, with slightly bluish gray reflection color. There is neither apparent pleochroism nor anisotropy. The chemical composition obtained by 

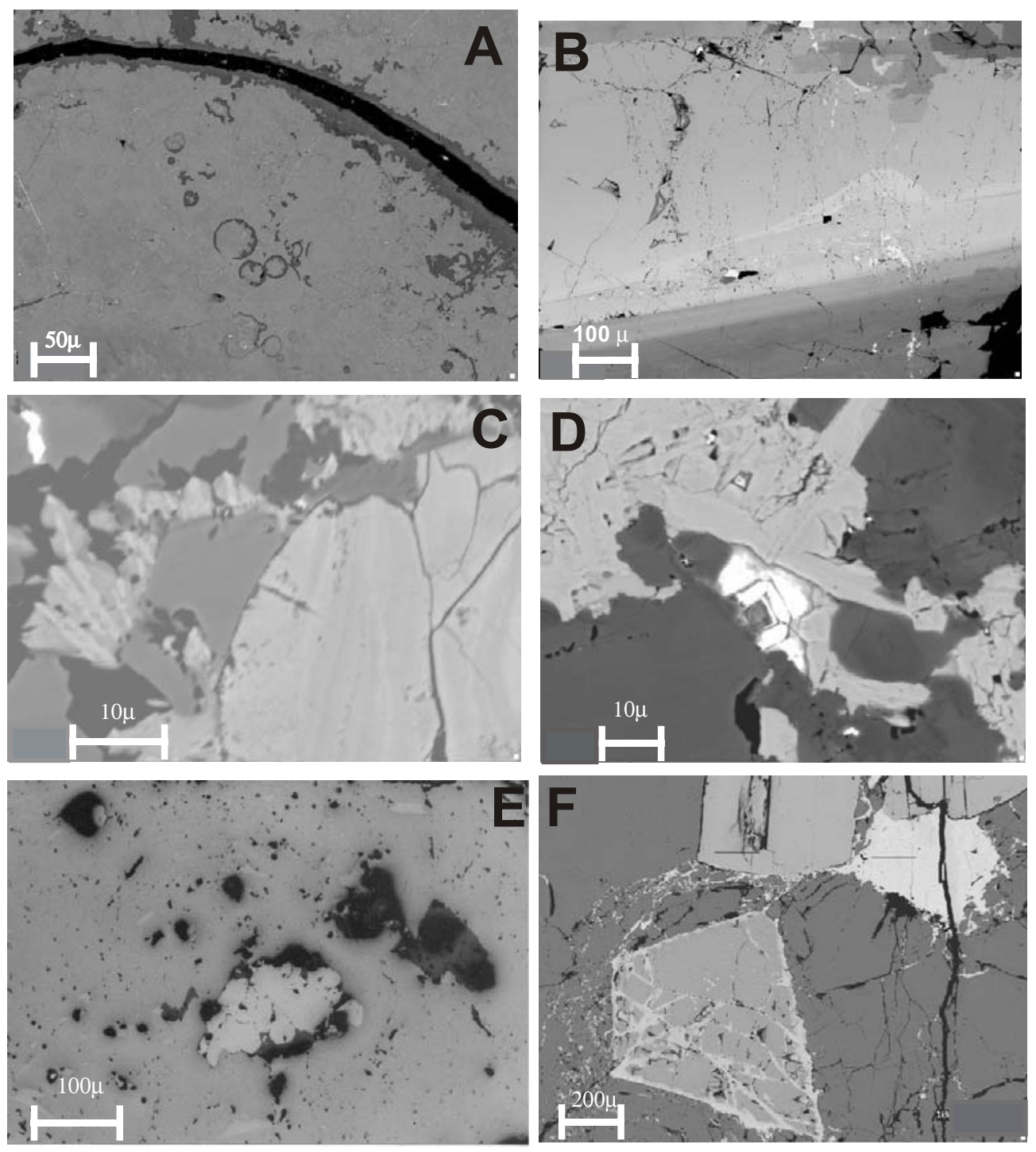

Fig. 3 - Backscanned SEM images: A) Brannerite showing the metamictic, collomorphic like micro-texture and gradual changes in "reflectivity" and composition. B) Titanian ixiolite crystal showing oscillatory compositional zoning with dark Ti-Nb-rich rims (top and bottom of the image) and Ta-Nb-rich, light, core. The small bright grains along fractures are microlite, pyrochlore and Ca-Ticolumbite. C) Light gray zoned Ca- Ti-bearing columbite inclusion with rounded contours, in the right side of the image, and a radial aggregate of tabular Ca-Ti columbite with slightly darker overgrowths of fersmite in a fracture of titanian ixiolite (dark gray). The white, fracture filling grain in the top left corner, is uranopyrochlore. D) The light gray/gray zoned cubic crystal in the center of the image is of uranmicrolite (white) and microlite (gray). The tabular gray crystal aggregate immediately above, is Ca-Ti-bearing columbite with slightly darker overgrowths, and interstitial fersmite, altogether filling a fracture in the dark titanian ixiolite. E) Cassiterite with small, slightly brighter ferrowodginite exsolutions and, in the center of the image, inclusion of a polygonal aggregate of light gray strüverite crystals. F) Simpsonite (dark gray matrix) with an idiomorphic inclusion of F-Na microlite (gray, in the center) and of tabular manganotantalite crystals in the top. The light gray mass enveloping the manganotantantalite is of microlite, with compositions ranging from stibio- to plumbomicrolite. The borders and cleavages of the microlite crystal are replaced by bario- (or parabario-) microlite (slightly darker gray hue than $\mathrm{Pb}$ - and $\mathrm{Sb}$-microlite). 
TABLE II

Microprobe analyses along a cross section of a titanian ixiolite crystal (same points represented in Figure 4C). Data from USP.

\begin{tabular}{|c|c|c|c|c|c|c|c|c|c|c|c|c|c|}
\hline weight $\%$ & $\begin{array}{c}\text { rim } \\
\text { qb862 }\end{array}$ & qb863 & qb864 & qb865 & qb866 & qb867 & qb868 & $\begin{array}{c}\text { core } \\
\text { qb869 }\end{array}$ & qb870 & qb871 & qb872 & $\begin{array}{c}\text { rim } \\
\text { qb873 }\end{array}$ & mean \\
\hline $\mathrm{Ta}_{2} \mathrm{O}_{5}$ & 11.09 & 12.80 & 23.31 & 26.28 & 23.14 & 28.51 & 31.24 & 43.41 & 28.13 & 17.30 & 11.58 & 11.71 & 22.37 \\
\hline $\mathrm{Nb}_{2} \mathrm{O}_{5}$ & 36.56 & 35.87 & 28.61 & 30.50 & 28.55 & 28.99 & 27.05 & 16.51 & 29.04 & 32.59 & 40.12 & 37.10 & 30.96 \\
\hline $\mathrm{TiO}_{2}$ & 30.92 & 29.20 & 24.89 & 18.99 & 27.05 & 19.19 & 19.53 & 18.46 & 18.27 & 28.99 & 25.60 & 30.08 & 24.27 \\
\hline $\mathrm{WO}_{3}$ & 0.00 & 0.00 & 0.00 & 0.00 & 0.00 & 0.00 & 0.00 & 0.00 & 0.00 & 0.00 & 0.00 & 0.00 & 0.00 \\
\hline $\mathrm{MnO}$ & 0.50 & 0.57 & 0.49 & 1.17 & 0.63 & 1.41 & 1.37 & 1.63 & 0.75 & 0.50 & 0.65 & 0.50 & 0.85 \\
\hline $\mathrm{Fe}_{2} \mathrm{O}_{3}$ (calc) & 18.15 & 18.15 & 18.26 & 17.59 & 16.44 & 16.03 & 15.75 & 13.32 & 15.67 & 16.66 & 17.63 & 17.74 & 16.78 \\
\hline $\mathrm{FeO}$ (calc) & 2.60 & 2.71 & 2.62 & 3.11 & 3.17 & 3.57 & 3.67 & 3.58 & 4.46 & 3.39 & 3.91 & 3.14 & 3.33 \\
\hline $\mathrm{FeO}$ & 19.10 & 19.21 & 19.23 & 19.11 & 18.12 & 18.15 & 17.99 & 15.69 & 18.70 & 18.54 & 19.94 & 19.26 & 18.58 \\
\hline $\mathrm{SnO}_{2}$ & 0.30 & 0.46 & 0.43 & 0.05 & 0.41 & 0.04 & 0.05 & 0.12 & 0.23 & 0.47 & 0.32 & 0.28 & 0.26 \\
\hline $\mathrm{CaO}$ & 0.01 & 0.00 & 0.00 & 0.00 & 0.02 & 0.00 & 0.00 & 0.00 & 0.00 & 0.00 & 0.00 & 0.00 & 0.00 \\
\hline $\mathrm{Na}_{2} \mathrm{O}$ & 0.06 & 0.02 & 0.01 & 0.01 & 0.01 & 0.00 & 0.00 & 0.00 & 0.00 & 0.00 & 0.00 & 0.03 & 0.01 \\
\hline $\mathrm{Al}_{2} \mathrm{O}_{3}$ & 0.31 & 0.37 & 0.22 & 0.34 & 0.32 & 0.36 & 0.36 & 0.41 & 0.22 & 0.32 & 0.33 & 0.29 & 0.32 \\
\hline Total & 100.5 & 100.1 & 98.85 & 98.11 & 99.74 & 98.17 & 99.01 & 97.50 & 96.77 & 100.2 & 100.1 & 100.9 & 99.17 \\
\hline \multicolumn{14}{|l|}{ apfu } \\
\hline $\mathrm{Ta}$ & 0.61 & 0.71 & 1.39 & 1.63 & 1.36 & 1.79 & 1.96 & 2.95 & 1.80 & 0.98 & 0.65 & 0.64 & 1.37 \\
\hline $\mathrm{Nb}$ & 3.33 & 3.31 & 2.83 & 3.15 & 2.78 & 3.03 & 2.83 & 1.86 & 3.09 & 3.07 & 3.74 & 3.38 & 3.03 \\
\hline $\mathrm{Ti}$ & 4.68 & 4.49 & 4.10 & 3.26 & 4.38 & 3.33 & 3.39 & 3.46 & 3.23 & 4.54 & 3.97 & 4.56 & 3.95 \\
\hline W & 0.00 & 0.00 & 0.00 & 0.00 & 0.00 & 0.00 & 0.00 & 0.00 & 0.00 & 0.00 & 0.00 & 0.00 & 0.00 \\
\hline $\mathrm{Mn}$ & 0.08 & 0.10 & 0.09 & 0.23 & 0.12 & 0.28 & 0.27 & 0.34 & 0.15 & 0.09 & 0.11 & 0.09 & 0.16 \\
\hline $\mathrm{Fe}_{3}$ (calc) & 2.75 & 2.79 & 3.01 & 3.03 & 2.67 & 2.78 & 2.74 & 2.50 & 2.77 & 2.61 & 2.74 & 2.69 & 2.76 \\
\hline $\mathrm{Fe}_{2}$ (calc) & 0.44 & 0.46 & 0.48 & 0.60 & 0.57 & 0.69 & 0.71 & 0.75 & 0.88 & 0.59 & 0.67 & 0.53 & 0.61 \\
\hline Sn & 0.02 & 0.04 & 0.04 & 0.00 & 0.04 & 0.00 & 0.00 & 0.01 & 0.02 & 0.04 & 0.03 & 0.02 & 0.02 \\
\hline $\mathrm{Ca}$ & 0.00 & 0.00 & 0.00 & 0.00 & 0.00 & 0.00 & 0.00 & 0.00 & 0.00 & 0.00 & 0.00 & 0.00 & 0.00 \\
\hline $\mathrm{Na}$ & 0.02 & 0.01 & 0.00 & 0.00 & 0.00 & 0.00 & 0.00 & 0.00 & 0.00 & 0.00 & 0.00 & 0.01 & 0.00 \\
\hline $\mathrm{Al}$ & 0.07 & 0.09 & 0.06 & 0.09 & 0.08 & 0.10 & 0.10 & 0.12 & 0.06 & 0.08 & 0.08 & 0.07 & 0.08 \\
\hline Total & 12.00 & 12.00 & 12.00 & 12.00 & 12.00 & 12.00 & 12.00 & 12.00 & 12.00 & 12.00 & 12.00 & 12.00 & 12.00 \\
\hline \multicolumn{14}{|l|}{ apfu ratios } \\
\hline $\mathrm{Nb}+\mathrm{Ta}+\mathrm{W}$ & 3.93 & 4.03 & 4.22 & 4.78 & 4.14 & 4.81 & 4.79 & 4.81 & 4.89 & 4.05 & 4.39 & 4.03 & 4.41 \\
\hline $\mathrm{Fe}^{*}+\mathrm{Mn}$ & 3.27 & 3.35 & 3.58 & 3.85 & 3.35 & 3.75 & 3.72 & 3.59 & 3.80 & 3.29 & 3.53 & 3.31 & 3.53 \\
\hline $\mathrm{Mn} /\left(\mathrm{Fe}^{*}+\mathrm{Mn}\right)$ & 0.026 & 0.029 & 0.026 & 0.059 & 0.035 & 0.073 & 0.072 & 0.096 & 0.040 & 0.027 & 0.032 & 0.026 & 0.04 \\
\hline $\mathrm{Ta} /(\mathrm{Ta}+\mathrm{Nb})$ & 0.154 & 0.177 & 0.329 & 0.341 & 0.328 & 0.372 & 0.410 & 0.613 & 0.368 & 0.242 & 0.148 & 0.160 & 0.30 \\
\hline$(\mathrm{Ta}+\mathrm{Nb}) / \mathrm{sum}$ & 0.330 & 0.338 & 0.354 & 0.402 & 0.347 & 0.405 & 0.402 & 0.405 & 0.409 & 0.340 & 0.369 & 0.338 & 0.37 \\
\hline$(\mathrm{Sn}+\mathrm{Ti}) / \mathrm{sum}$ & 0.395 & 0.380 & 0.346 & 0.275 & 0.371 & 0.280 & 0.286 & 0.293 & 0.272 & 0.384 & 0.336 & 0.385 & 0.33 \\
\hline$\left(\mathrm{Fe}^{*}+\mathrm{Mn}\right) / \mathrm{sum}$ & 0.275 & 0.282 & 0.300 & 0.323 & 0.282 & 0.315 & 0.312 & 0.302 & 0.318 & 0.276 & 0.296 & 0.278 & 0.30 \\
\hline
\end{tabular}

EMP indicates $\mathrm{Ta}_{2} \mathrm{O}_{5}(64 \mathrm{wt} \%), \mathrm{Bi}_{2} \mathrm{O}_{3}(20 \mathrm{wt} \%)$, $\mathrm{Nb}_{2} \mathrm{O}_{5}$ (5 wt\%), $\mathrm{CaO}$ (2.7), $\mathrm{Na}_{2} \mathrm{O}$ (1.3) and $\mathrm{MnO}$ (1.2 wt \%) and $\mathrm{Cs}_{2} \mathrm{O}$ (up to $4.0 \%$ ) as main constituents. The important $\mathrm{Cs}$ contents could only be determined semi-quantitatively, because of the lack of adequate standards. The metamict nature indicates also the presence of important contents of a non analyzed radioactive element, probably Th, because of the low determined $\mathrm{U}$ contents, below $0.02 \%$. The composition, as determined above, is very consistent along three points of the analyzed grain. High Bi-tantalates include bismutotantalite, bismutomicrolite, natrobistantite and "IMA 1998018" as possible species. The common bismutotantalite does not contain $\mathrm{Ca}, \mathrm{Na}$ and $\mathrm{Cs}$, and metamict varieties are also unknown. The other possibilities are all minerals of the pyrochlore group, microlite $(\mathrm{Ta}>\mathrm{Nb}$ ) subgroup. The usual bismutomicrolite compositions present a strong dominance of $\mathrm{Ca}$ over $\mathrm{Na}$ and only traces of $\mathrm{Cs}$ in the A site, while 

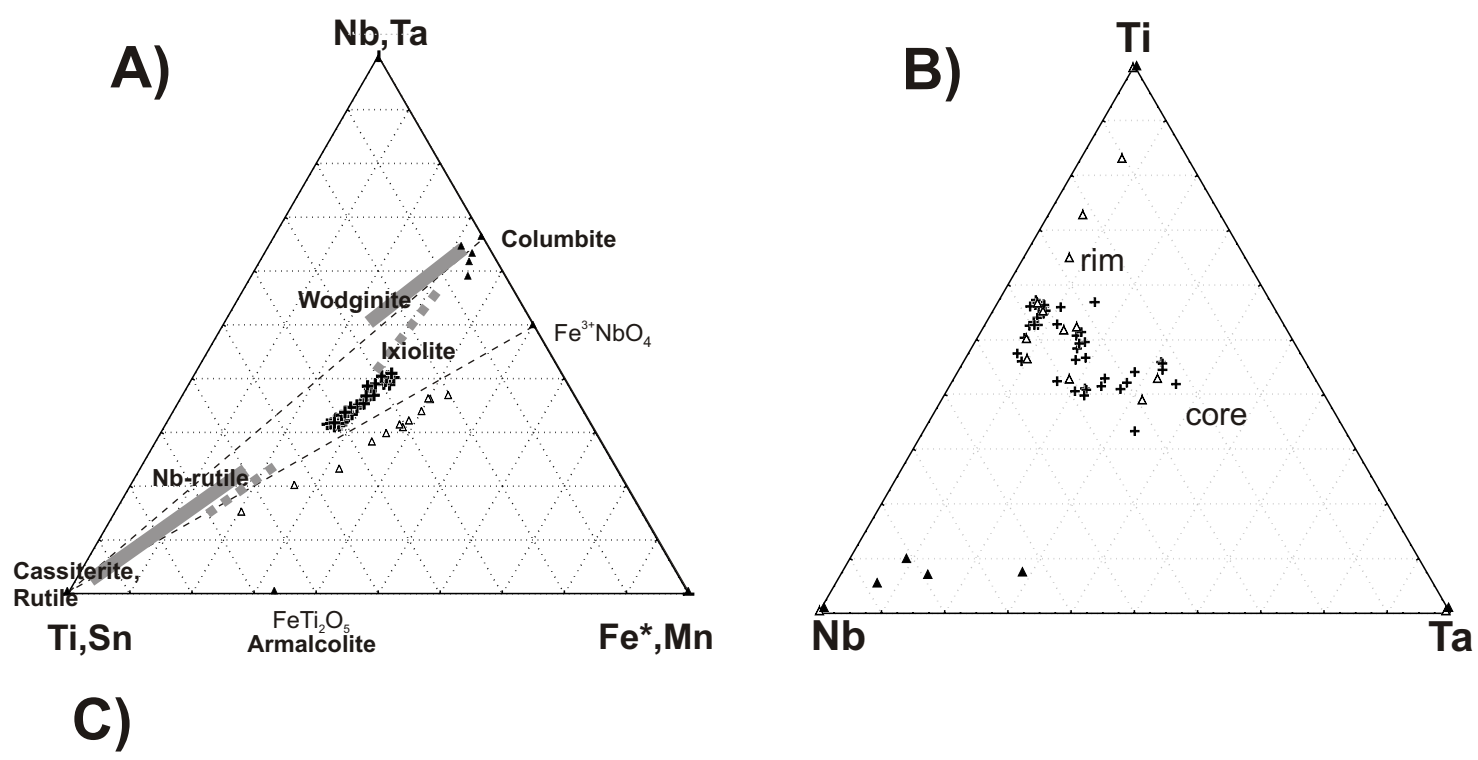

Compositional range along a cross section of a titanian ixiolite crystal from the Quintos pegmatite

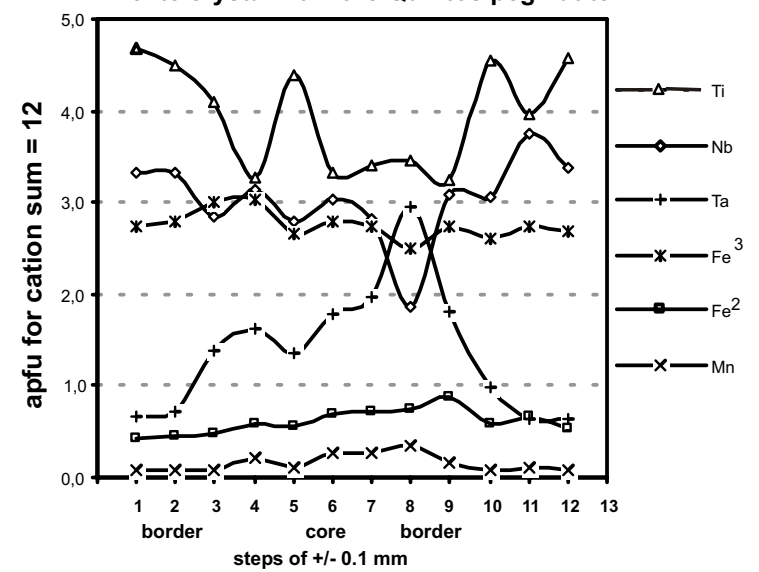

Fig. 4 - A) Compositional range of titanian ixiolite from the Quintos pegmatite in the Ti, Sn vs. Fe, Mn vs. Nb, Ta apfu diagram compared with data on niobian rutile and ixiolite- columbite pairs in equilibrium, reported by Uher et al. (1998a, large gray dots) and Černý et al. (1998, large gray bars). The EMP data from Quintos (x) are $\mathrm{Fe}^{3+}$ corrected to compensate the excess of total cations, while in the SEM data (triangles) total iron is in $\mathrm{Fe}^{2+}$. B) $\mathrm{Nb} / \mathrm{Ta} / \mathrm{Ti}$ plot of the same data. Full triangles stand for columbite inclusions in the ixiolite. C) Compositional range along a cross section indicating a general trend of Ti enrichment towards the border and of Ta in the core, but with various oscillatory substitution mechanisms, also shown by the sinuous line formed by the data in Fig. 4B.

in both, natrobistantite and IMA 1998-018, Na distinctly prevails over $\mathrm{Ca}$. In the case of natrobistantite, important contents of Cs are also registered. In none of them manganese contents are referred to. So it seems that the composition that mostly approaches that of the focused case is that of natrobistantite. The status of natrobistantite, first identified and proposed by Voloshin et al. (1983) as an independent mineral species, is still not approved by IMA and questioned by Černý and Ercit (1989) as probably being a variety of bismutomicrolite. In the case of IMA 1998-018 the absence of $\mathrm{Cs}$ and important $\mathrm{F}$ contents standing for $(\mathrm{OH})$ in the $\mathrm{X}$ site distinguish this species from usual NBT 


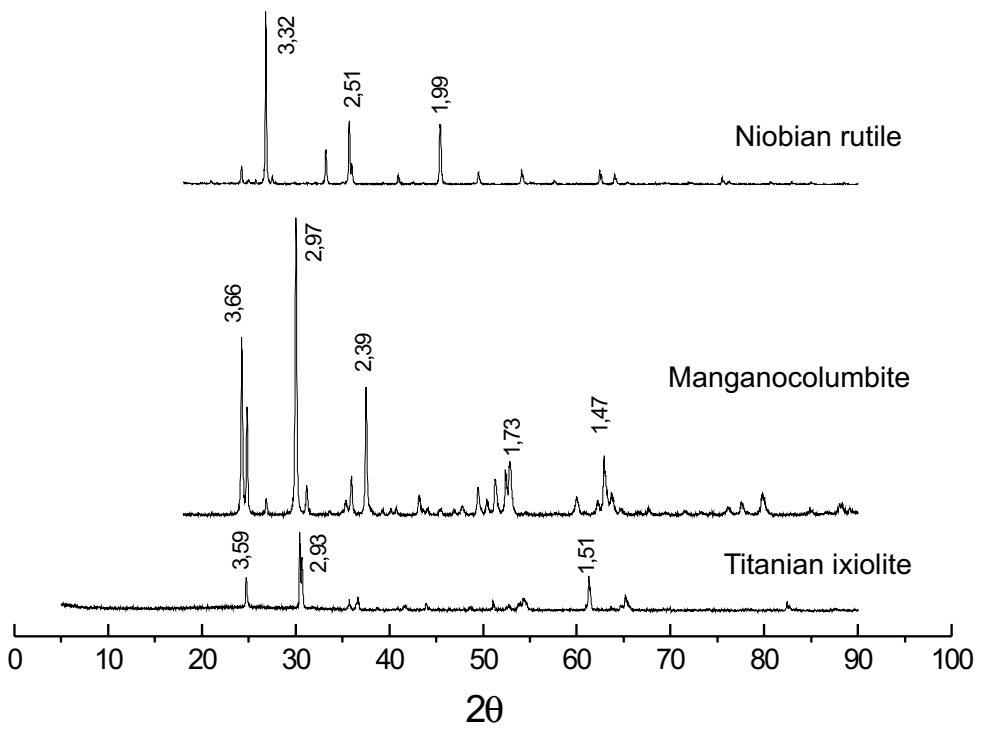

Fig. 5 - X-ray diffractograms of titanian ixiolite and niobian rutile from the Quintos pegmatite in comparison with those for manganocolumbite from the Boqueirão pegmatite in the Borborema Pegmatitic Province, Northeast Brazil.

and also from the examined mineral. New analyses including F, Cs, and Th are still under way.

If the classification of the pyrochlore group is applied strictly according to Hoggarth (1977), the studied mineral should be identified as bismutomicrolite but, this would also be the case of the natrobistantite of Voloshin, as far as no crystal refinement distinguishing a peculiar structural type is available (Černý and Ercit 1989). New and larger samples are necessary to obtain reliable $\mathrm{X}$-ray data of the studied mineral.

Nevertheless, neither the occurrence of bismutomicrolite nor that one of natrobistantite is referred to in the most important mineralogical reviews on the BPP, beginning with the first and most complete one by Rolff 1946, to the most recent ones by Da Silva (personal communication) and Soares (personal communication). The work by Adusumilli (1978), specialized in tantalate mineralogy of the BPP, also does not contain any reference on bismutomicrolite or natrobistantite. During the present search there was found only one reference on bismutomicrolite in the Jacu and Baldino pegmatites of the BPP but, with the qualification of unconfirmed, in the site www.mindat.org./min-633.html (2003).

Other minerals of the pyrochlore group in the Quintos pegmatite found in the present study, in contrast with the minerals described above, occur as microscopic grains and $\mathrm{Cs}_{2} \mathrm{O}$ films, products of late hydrothermal alteration in fractures of the titanian ixiolite described above. The compositions are very variable from grain to grain and frequently also along different crystal zones in the same grains. In the case of Quintos, both uranmicrolite and uranpyrochlore grains were identified. Uranpyrochlore was also found in fractures of manganocolumbite of the Serraria and Boqueirão pegmatites, and plumbo- and stibiomicrolite as alteration of simpsonite of the Alto do Giz pegmatite (Figure 3F, Table I). While the occurrence of common microlite, uranmicrolite, bario- and parabariomicrolite is well documented in the literature (Rolff 1946, Ercit et al. 1986 and many others) there is no reference on uranpyrochlore and plumbomicrolite in the BPP so far.

Strüverite is another mineral identified during 
this study, so far unknown in the BPP. It has been found in the homogeneous albite-rich Corredor pegmatite, enclosed in the schists of the Serido formation. It occurs as occasional micro-aggregates of polygonal shaped, $20 \mu \mathrm{m}$ sized grains (Figure 3E) and as rare smaller exsolutions (less than $20 \mu \mathrm{m}$ long), included in cassiterite, together with dominant exsolutions of ferrowodginite $(0.2$ to $20 \mu \mathrm{m}$ large). Some ferrotapiolite inclusions were also identified. The strüverite grains consistently contain about $45 \% \mathrm{Ta}_{2} \mathrm{O}_{5}, 29 \mathrm{wt} \% \mathrm{TiO}_{2}, 6,8 \% \mathrm{Nb}_{2} \mathrm{O}_{5}$, $13 \% \mathrm{Fe}_{2} \mathrm{O}_{3}$ and 6 to $10 \mathrm{wt} \% \mathrm{SnO}_{2}$. The dominance of the rutile component $(\mathrm{Ti}+\mathrm{Sn}$ apfu $\gg 4$ for a cation sum of 12) over the $\mathrm{Ta}+\mathrm{Nb}+\mathrm{Fe}$ component and $\mathrm{Ta} \gg \mathrm{Nb}$ are characteristic and unique of strüverite, but the Ta-contents are much higher than the usual 10-20 wt\% observed in the literature (e.g. Černý and Ercit 1989). The only occurrence of strüverite in Northeast Brazil was referred to by Adusumilli (1978) in a pegmatite of the Icozinho pegmatite field in the State of Ceará, far from the BPP.

The strüverite-ferrowodginite hosting cassiterite crystal is also very interesting because of its peculiar compositional zoning: some growth zones are formed by quite pure cassiterite hosting well formed and crystallographically oriented, 5 to $20 \mu \mathrm{m}$ sized lamellae of ferrowodginite exsolutions. Other zones of pure cassiterite contain even larger up to $50 \mu \mathrm{m}$ in size, idiomorphic grains of wodginite with chaotic, irregular and disoriented distribution, supposedly the result of coalescent recrystallization of minor exsolutions. In contrast, there are zones with clouds of very fine, bleb shaped, randomly oriented, 1 to $5 \mu \mathrm{m}$ sized, emulsion like exsolutions and other zones that, apparently homogeneous under the microscope, present slightly higher reflectivity caused by submicroscopic $0.2 \mu \mathrm{m}$ sized emulsion like exsolutions which could be distinguished only in BSE images of the SEM. Other zones are apparently homogeneous even under higher magnifications of the SEM. They are somewhat brighter, and supposedly have compositions similar to that of the discredited mineral "staringite", with up to $15 \mathrm{~mol} \%$ normative $\mathrm{FeTa}_{2} \mathrm{O}_{6}$ in the cassiterite that may represent areas were the cassiterite presents ferrowodginite emulsion like exsolutions, smaller than $0.2 \mu \mathrm{m}$. In these zones only mixed analyses of this composition are obtained in SEM or EMP, representing the composition of the high temperature precursor, a solid solution of cassiterite, tapiolite and rutile, as supposed by Groat et al. (1994). The main difference of the present case with the supposition of Groat et al. (1994) is that the exsolutions are not of tapiolite but of ferrowodginite.

\section{DISCUSSION AND CONCLUSIONS}

During lithogeochemical and fluid inclusion studies in some pegmatites of the BPP the petrographic and chemical analysis of some black ore minerals found by accident, allowed to determine several uncommon tantalates until now unknown in this province, namely brannerite, high titanian ixiolite, fersmite, stibio-, plumbo- and bismutomicrolite or natrobistantite, uran- and plumbopyrochlore and strüverite. Based on the occurrence of well formed crystals it is suggested that brannerite, titanian ixiolite, strüverite and natrobbistantite are primary magmatic phases, while fersmite and the other minerals of the pyrochlore and microlite subgroups, according to the occurrence in fractures of the primary tantalates, were formed during a later hydrothermal alteration stage. The presence of these "exotic" microlite varieties is typical of the late stages in highly evolved pegmatite types, according to Černý and Ercit (1985).

The unusual oscillatory "reverse" compositional zoning pattern observed in the titanian ixiolite with $\mathrm{Nb}, \mathrm{Fe}$ and $\mathrm{Ti}$ enrichment towards the borders at expense of Ta- and Mn-enriched cores is also observed in highly evolved pollucite producing pegmatites in Northwestern Ontario, Canada, according to Tindle and Breaks (2000). These observations, in addition to the merely mineralogical interest, allow to suppose that several pegmatites of the Borborema Province may have reached higher degrees of frac- 
tionation than previously supposed, based on lithogeochemical data (da Silva et al. 1995) as being of the beryl-columbite type.

As a consequence, the occurrence of high grade pollucite (Cs) and/or petalite ( $\mathrm{Li}$ ) mineralizations in the province must be considered as a real possibility. Last not least an illustrative example of unexpected mineralization discoveries in pegmatite areas supposed to be well known, and the need to perform always more detailed research in such areas should be emphasized: the main pollucite producing pegmatites in the Separation Rapids pegmatite field were discovered only several decades after the knowledge of this and other pegmatite fields in the same province, and represent one of the most important source of $\mathrm{Cs}$ and $\mathrm{Ta}$ ores of the world today. It becomes also clear that much more detailed and systematic research has to be done on Ta-Nb-oxide mineralogy and geochemistry in the Borborema Pegmatite Province.

\section{ACKNOWLEDGMENTS}

This research was supported by Conselho Nacional de Desenvolvimento Científico e Tecnológico (CNPq) Grant 470199/01-6. We are also indebted to Dr. W. Heinrich of the GeoForschungsZentrum Potsdam in Germany for the free use of the Microprobe facility, to Prof. Excelso Ruperti for the help during the microprobe analyses at the Instituto de Geociências, Universidade de São Paulo (USP), Brazil and to Dailto Silva for the SEM analyses at the Instituto de Geociências, Universidade Estadual de Campinas (UNICAMP), Brazil.

\section{RESUMO}

Amostras de tantalatos, supostamente do grupo das columbitas foram coletadas na Província Pegmatítica da Borborema na perspectiva de testar as razões $\mathrm{Mn} /(\mathrm{Mn}+\mathrm{Fe})$ e $\mathrm{Ta} /(\mathrm{Ta}+\mathrm{Nb})$ como indicadores do grau de fracionamento dos pegmatitos. Resultados preliminares de microssonda permitiram, surpreendentemente, reconhecer espécies incomuns de tantalatos desconhecidos na província, como titano-ixiolita, brannerita, fersmita strüverita, natrobistantita, plumbo- e stibiomicrolita, plumbo- e uranopiro- cloro. A identificação destes tantalatos exóticos e com composições inusitadas, somados à sua ocorrência em vários pegmatitos longe das ocorrências Alto do Giz e Seridozinho, classicamente conhecidas como portadores de espécies exóticas, indicam que o elevado grau de fracionamento não é restrito a estas duas ocorrências, mas pode ser atingido também em outras áreas. Indica também que o grau de fraciononamento pode variar bastante em diferentes pegmatitos de pequenas áreas. Os padrões de zoneamento observados na titano-ixiolita, com enriquecimento de Ti e Nb nas bordas às expensas de Ta enriquecido no núcleo, são também incomuns e contrários ao usual enriquecimento progressivo de Ta e Mn com o grau de fracionamento. Trend similar e designado como reverso, foi observado em columbitas e titanowodginitas de pegmatitos produtores de pollucita e/ou petalita na Província Pegmatítica de Separation Rapids, no Ontário, Canadá.

Palavras-chave: titano-ixiolita, fersmita, brannerita, struverita, nióbio-tantalatos, pegmatitos, Nordeste do Brasil.

\section{REFERENCES}

AdUSUMILli MPS. 1978. Nióbio-tantalatos do Nordeste do Brasil: a série columbita-tantalita. Jornal de Mineralogia 7: 195-225.

Almeida FFM, Melcher GC, Cordani UG, KawaShita K AND VANDOROS P. 1968. Radiometric age determinations from Northern Brazil. São Paulo: Soc Bras Geol Bol 17: 3-15.

Antony JW, Bideaux RA, Bladh KW and Nichols MC. 1997. Handbook of Mineralogy. Volume III Halides, Hydroxides, Oxides. Tucson, Arizona, USA. Mineral Data Publishing, 597 p.

ATÊNCIO D. 2000. Type Mineralogy of Brazil. Special Publication, Inst. Geosciences, University of São Paulo, 114 p.

Aurisichio D, De Vito C, Ferrini V and Orlandi P. 2002. $\mathrm{Nb}$ and Ta oxide minerals in the Fonte Del Prete granitic pegmatite dike, Island of Elba, Italy. Can Min 40: 799-814.

Beurlen H, Da Silva MRR and Castro C. 2001. Fluid inclusion microthermometry in Be-Ta-(Li-Sn) bearing pegmatites from the Borborema Province, Northeast Brazil. Chem Geol 173: 107-123.

Beurlen H, Soares DR, Borges LEP, Villaroel HS AND Da SiLva MRR. 2003. Análise de mecanismos de substituição em tantalato exótico: provável titano- 
ixiolita na Província Pegmatítica da Borborema. Rev Geol UFC 16: 7-18.

Brito Neves BB, Van Schmus WR, Santos EJ, Campos Neto MC and Kozuch M. 1995. O evento Cariris Velhos na Província Borborema: integração de dados, implicações e perspectivas. Rev Bras Geoc 25: 279-296.

Burke EAJ, Kieft C, Ofelius R and Adusumilli MPS. 1969. Staringite a new Sn-Ta-mineral from Northeastern Brazil. Min Magazine 37: 447-452.

Burke EAJ, Kieft C, Ofelius R And Adusumilli MPS. 1970. Wodginite from Northeastern Brazil. Geol Mijnbow 49: 235-240.

ČERnÝ P AND ERCIT TS. 1985. Some recent advances in the mineralogy and geochemistry of $\mathrm{Nb}$ and $\mathrm{Ta}$ in rare-element granitic pegmatites. Bull Mineral 108: 499-532.

ČERnÝ P AND ERCIT TS. 1989. Mineralogy of Niobium and Tantalum:crystal Chemical relationships, paragenetic aspects and their implications. In: MoELLER P, ČERnÝ P And SAupé F. 1989. Lantanides, Tantalum, Niobium. Heidelberg: Springer, p. 27-79.

Černý P, ERCIT TS, Wise MA, Chapman R and Buck HM. 1998. Compositional structural and phase relationships in titanian ixiolite and titanian columbitetantalite. Can Mineral 36: 547-562.

Da Silva MRR, Höll R And Beurlen H. 1995. Borborema Pegmatitic Province: geological and geochemical characteristics. Journ South Am Earth Sciences 8: 355-364.

Ebert H. 1969. Geologia do Alto Seridó. Recife, Brazil. SUDENE, Serie Geol Reg 11: 120.

Ercit TS, Hawthorne FC And Černý P. 1985. The crystal structure of synthetic natrotantite. Bull Min 108: 541-549.

Ercit TS, Hawthorne FC And Černý P. 1986. Parabariomicrolite, a new species and its structural relationship to the pyrochlore group. Can Mineral 24: 655-663.

ErCit TS, Hawthorne FC And Černý P. 1992a. The crystal structure of alumotantite its relations to the structure of simpsonite and the $(\mathrm{AlGa})(\mathrm{TaNb}) \mathrm{O}_{4}$ compounds. Can Mineral 30: 653-662.

Ercit TS, Hawthorne FC And Černý P. 1992b. The wodginite group I: structural crystallography. Can Mineral 30: 597-612.
Ercit TS, Černý P, Hawthorne FC and McCammon CA. 1992c. The wodginite group II: crystal chemistry. Can Mineral 30: 613-632.

Ercit TS, ČernÝ P ANd Hawthorne FC. 1992d. The wodginite group III: classification and new species. Can Mineral 30: 633-638.

Ercit TS, Černý P ANd Hawthorne FC. 1992e. The crystal chemistry of simpsoinite. Can Mineral 30: 663-672.

Groat Le, Putnis A, Kissin SA, Ercit TS, HawTHORNe FC AND GaInes RV. 1994. Staringite discredited. Mineralogical Magazine 58: 271-277.

Hoggarth DD. 1977. Classification and nomenclature of the pyrochlore group. Am Mineral 62: 403-410.

JARDim de SÁ EF, Legrand JM AND MCReath I. 1981. Estratigrafia de rochas granitóides na Região do Seridó (RN-PB) com base em critérios estruturais. Rev Bras Geoc 11: 50-57.

JohNSTON JR WD. 1945. Beryl-tantalite pegmatites of Northeastern Brazil. Geol Soc Amer Bul 56: 10151070.

Rolff PMA. 1946. Minerais dos pegmatitos da Borborema. Rio de Janeiro, DNPM Div Fom Prod Min Bol 78: 23-76.

Tindle AG and Breaks FW. 2000. Columbite-tantalite mineral chemistry from rare element granitic pegmatites: Separation Lake area, NW Ontario, Canada. Min Petrol 70: 165-198.

Tindle AG, Breaks FW and Webb PC. 1998. Wodginite-group minerals from the Separation Rapids rareelement granitic pegmatite group, Northwestern Ontario. Can Mineral 36: 637-658.

Uher P, Černý P, Chapman R, Hatar J and Miko O. 1998a. Evolution of Nb,Ta-oxide minerals in the Prasiva Granitic Pegmatites Slovakia. I: Primary Fe,Tirich assemblage. Can Mineral 36: 525-534.

Uher P, Černý P, Chapman R, Hatar J and Miko O. 1998b. Evolution of Nb,Ta-oxide minerals in the Prasiva Granitic Pegmatites Slovakia. II. External hydrothermal $\mathrm{Pb}, \mathrm{Sb}$ overprint. Can Mineral 36: 535-546.

Voloshin AV, Pakhomovskyi YaA, Stepanov VI And Tyusheva FN. 1983. Natrobistantite, (Na,Cs) $\mathrm{Bi}(\mathrm{Ta}, \mathrm{Nb}, \mathrm{Sb}) 4^{\circ} 12$ - new mineral from granitic pegmatites. Min Zh 5: 82-86. 